\title{
ERRATUM
}

\section{Lay Brothers: The Other Men in the MENDicant ORders OF NeW SPAIN-ERRATUM}

\author{
Asunción Lavrin
}

doi: 10.1017/tam.2015.32, Published by Cambridge University Press 20 November, 2015.

The original publication of this article contained an incorrect email address for the author. The correct address is reproduced below.

<lavrin64@gmail.com>

The publisher regrets the error.

\section{REFERENCE}

Asunción Lavrin (2015). Lay Brothers: The Other Men in the Mendicant Orders of New Spain. The Americas, 72(3), pp. 411-438. doi: 10.1017/tam.2015.32 